\title{
Journal of Cereal Research
}

13(3): 305-312

\section{Field efficacy of flubendiamide 20WG against rice leaf folder, Cnaphalocrocis medinalis (Guenee) and yellow stem borer, Scirpophaga incertulas (Walker) in basmati rice}

\author{
Maha Singh Jaglan* and Om Pal Chaudhary \\ CCS Haryana Agricultural University, Regional Research Station, Karnal, Haryana, India-132001
}

\section{Article history:}

Received: 2 Dec., 2021

Revised: 23 Dec., 2021

Accepted: 27 Dec., 2021

\section{Citation:}

Jaglan MS and OP Chaudhary. 2021. Field efficacy of flubendiamide $20 \mathrm{WG}$ against rice leaf folder, Cnaphalocrocis medinalis (Guenee) and yellow stem borer, Scirpophaga incertulas (Walker) in basmati rice. Journal of Cereal Research 13(3): 305-312. http://doi. org/10.25174/2582-2675/2022/118847

\section{*Corresponding author:}

E-mail: jaglanms@gmail.com

(C) Society for Advancement of Wheat and Barley Research

\begin{abstract}
Rice leaf folder, Cnaphalocrocis medinalis (Guenee) and yellow stem borer, Scirpophaga incertulas (Walker) are the two major insect pests of rice causing considerable damage in India. Various strategies have been employed for managing these insect pests and insecticides as chemical control factors are the first line of defense. Thus, identification of new molecules with selective properties, novel mode of action, low toxicity to non-targets and environmental safety is required with a view of sustainable pest management. A number of novel insecticides have been registered for insect control in agriculture. A major advantage of these insecticides is that they act on insect biological processes and also have greater selectivity to target specific species. Therefore, flubendiamide 20 WG was evaluated at farmers' field in basmati rice during Kharif, 2020 to access its efficacy against rice leaf folder and yellow stem borer. Foliar spray of flubendiamide 20 WG @ $25 \mathrm{~g}$ a.i. ha ${ }^{-1}$ effectively reduced the infestation of rice leaf folder and yellow stem borer. Foliar application of flubendiamide $20 \mathrm{WG}(25 \mathrm{~g}$ a.i. ha1) did not cause any phyto toxicity symptoms on the crop. Average grain yield (37.14 $\mathrm{q} \mathrm{ha}^{-1}$ ) was observed in twice foliar application of flubendiamide 20 WG @ 25 gm a.i. ha ${ }^{-1}$ as compared to control $\left(32.24 \mathrm{q} \mathrm{ha}^{-1}\right)$.
\end{abstract}

Keywords: Flubendiamide, phytotoxicity, rice leaf folder, yellow stem borer.

\section{Introduction}

Rice (Oryza sativa L.), is one of the staple foods for more than half of the world population and an important target to secure food security and livelihoods for millions of people. The productivity of rice in India is quite low (3.01 tons $\mathrm{ha}^{-1}$ ) as compared to world average of 4.02 tons ha ${ }^{-1}$ (Anonymous, 2012). Among the various factors, insect pests cause serious losses in yield of rice in India. About 100 insect species are known to attack rice crop and 20 of them are consistently reported as major pests (Rahaman and Stout, 2019). Among these rice leaf folder, Cnaphalocrocis medinalis and yellow stem borer, Scirpophaga incertulas are the most important pests of rice in India. Rice leaf folder earlier considered as a minor pest has attained status of the major pest with the widespread adoption of high yielding rice varieties and accompanying changes in the cultural practices (Teng et al., 1993). Larva fastens the edges of leaves together, fold them longitudinally and feed on the green matter from inside the folded leaf. Damaged leaves produce white streaks, become membranous and ultimately photosynthetic activity of the plant is reduced. Muhammad et al. (2012) reported that percentage of filled grains and grain yield varied significantly with rice leaf folder infestation levels. Yellow stem borer is the dominant species among the rice pests in India. Rice plants are most 
prone to yellow stem borer infestation at tillering and flowering stages. If control measures are not adopted, yield loss may expect up to 87.66 per cent by this pest (Pallavi $e t$ al., 2017). Stem borer larvae damage central whorl of the plants which then turn brownish and dries up resulting in "dead hearts". At reproductive stage, the damage is characterized by whitish, erect and chaffy panicles called, "white ears" (Muralidharan and Pasalu, 2006). Various strategies have been employed for managing these pests but insecticides as chemical control factors are first line of defense. In the last century, extensive use of persistent, broad spectrum and inexpensive pesticides in agriculture has led to severe concerns regarding public and environmental health. A number of novel insecticides have recently been registered for insect control in agriculture. A major advantage of these new insecticides is that they act on insect biological processes and also have greater selectivity to target specific species, so they may less likely to harm natural enemies when compared with the broader spectrum organophosphate, carbamate, neonicotinoid and pyrethroid insecticides. Flubendiamide ( $\mathrm{N}^{2}$-[1,1-dimethyl-2-methyl sulphonyl ethyl]-3-iodo- $\mathrm{N}^{1}$ 2-methyl-4-\{1,2,2,2-tetrafluro-1-(trifluromethyl) ethyl $\}$ phenyl), a phthalic acid diamide insecticide, belongs to the benzene dicarboxamide group of insecticides. Unlike other conventional insecticides which target insect nervous system, flubendiamide is systemic and acts at receptors in insect muscles through the activation of ryanodine-sensitive intracellular calcium release channels (ryanodine receptors, RyR), causing immediate cessation of feeding (Tohnishi et al., 2005). Flubendiamide 20WG is a registered insecticide by Central Insecticide Board \& Registration Committee at a dose of $25 \mathrm{~g}$ a.i./ha against rice leaf folder and yellow stem borer in rice. Keeping these points in view, present experiment was conducted to evaluate the efficacy of flubendiamide 20WG against rice leaf folder and yellow stem borer in basmati rice at farmers' field.

\section{Materials and Methods}

Field efficacy of flubendiamide $20 \mathrm{WG}$ against rice leaf folder, Cnaphalocrocis medinalis and yellow stem borer, Scirpophaga incertulas was tested at farmers' field at 10 multi- locations in Karnal, Kurukshetra and Kaithal districts using basmati rice (variety CSR 30) during Kharif, 2020. Test insecticide flubendiamide $20 \mathrm{WG}$ was evaluated at $25 \mathrm{~g}$ a.i. ha ${ }^{-1}$ and compared with untreated control. The crop was raised as per standard recommended package of practices of CCS Haryana Agricultural University, Hisar (Anonymous, 2019). However, tested insecticide for rice leaf folder and yellow stem borer were applied in treated plots. The rice seedlings were transplanted during kharif, 2020 at farmers' fields at 10 multi-locations with plot size of one acre per trial for treated and untreated control. Insecticide was sprayed twice in 500 liters of water per ha with a knapsack sprayer. First spray of insecticide was done at tillering stage at 30 days after transplanting (DAT) and second at panicle initiation stage (50 DAT) or when pest population crossed economic threshold level. Rice leaf folder and yellow stem borer infestation were recorded at 1 day before application of insecticide and at 5, 10 \& 15 days after both sprays. For recording rice leaf folder damage, 10 hills were selected at random from each plot. For this, total number of leaves on 10 hills and damaged leaves (rolled leaves with live larvae) were recorded and per cent leaf damage was worked out. For recording yellow stem borer damage, total number of plants and dead hearts were recorded from 10 hills selected at random at different intervals and per cent dead hearts were worked out. The yield was recorded separately from each plot and then converted into per hectare basis. Incremental cost: benefit ratio was calculated on basis of additional net income from insecticidal application and total cost of insecticide and its application. Data was analyzed on basis of average infestation of rice leaf folder and yellow stem borer at different intervals and decrease in pest population over untreated control.

Phytotoxic effects caused by flubendiamide 20 WG were also evaluated in the above-mentioned plots. Ten plants were randomly selected from each plot along with untreated control and examined at 5, 10 and 15 DAS for the phyto toxicity symptoms viz., leaf tip burning, leaf chlorosis, vein clearing, leaf necrosis, leaf epinasty, leaf hyponasty, wilting, stunting and hyponasty on a scale of 0-10 (Ambarish et al., 2017). 
Leaf injury scale for determining phyto toxicity in rice plants

\begin{tabular}{cc}
\hline Scale/score & Phyto toxicity (\%) \\
\hline 0 & No phytotoxicity \\
1 & $1-10$ \\
2 & $11-20$ \\
3 & $21-30$ \\
4 & $31-40$ \\
5 & $41-50$ \\
6 & $51-60$ \\
7 & $61-70$ \\
8 & $71-80$ \\
9 & $81-90$ \\
10 & $91-100$ \\
\hline
\end{tabular}

\section{Results and Discussion}

Data on rice leaf folder infestation recorded from 10 multi-location trials during Kharif, 2020 are presented in Tables 1-2. Results indicate that rice leaf folder infestation (rolled leaves with live larvae) from different locations was recorded on an average of $6.21 \%$ infested leaves (treated) and $6.27 \%$ (untreated control) before first insecticidal application indicating the uniform population in treated and untreated control plots. Rice leaf folder infestation at 5 days after application of flubendiamide $20 \%$ WG @ $25 \mathrm{~g}$ a.i. ha ${ }^{-1}$ at tillering stage (30 DAT) ranged from 0.71 to $1.06 \%$ as compared to $6.07-6.91 \%$ infested leaves in untreated control (Table 1). Corresponding figures for mean infestation of rice leaf folder was 0.89 and $6.58 \%$ at 5 days after spray (DAS). Mean rice leaf folder infestation at 10 days after application of insecticide was recorded $1.00 \%$ as against $6.89 \%$ in untreated control. Pest population increased markedly at 15 days after application of insecticide and it was recorded $1.53 \%$ as compared to $7.33 \%$ in untreated control (Table 1). Per cent reduction in rice leaf folder infestation recorded from different locations ranged from 60.34 to $67.43 \%$ with mean of $64.39 \%$. Similar trend was recorded in rice leaf folder infestation after second spray (Table 2). It was recorded $2.56 \%$ infested leaves as against $7.42 \%$ in untreated control before application of second spray. Minimum infestation (0.67\%) was reported at 5 days after application of second spray as compared to $7.59 \%$ in untreated control. Infestation of rice leaf folder increased 10 days after application. Rice leaf folder infestation was recorded $1.18 \%$ infested leaves as compared to $7.99 \%$ in untreated control (Table 2). Mean per cent reduction over control was recoded $82.47 \%$.

Data on yellow stem borer is presented in Tables 3-4. Results indicate that yellow stem borer infestation from different locations ranged from 4.87 to $5.62 \%$ dead heart (treated plots) and 5.19 to $5.72 \%$ dead heart (untreated plots) before first insecticidal application with mean infestation of 5.33\% (treated) and 5.50\% (untreated control). Yellow stem borer infestation at 5 days after application of flubendiamide 20\% WG @ $25 \mathrm{~g}$ a.i. ha ${ }^{-1}$ at tillering stage (30 DAT) ranged from 2.02 to $2.34 \%$ dead heart as compared to 5.21 to $6.81 \%$ in untreated control (Table 3). Corresponding figures for mean infestation was 2.18 and $5.86 \%$. Average infestation of yellow stem borer at 10 days after application of insecticide was recorded 1.71\% as against $6.09 \%$ in untreated control. Pest population increased markedly at 15 days after application of first spray and it was recorded $1.80 \%$ as compared to $6.21 \%$ in untreated control (Table 3). Per cent reduction in stem borer infestation recorded from different locations ranged from 50.44 to $57.45 \%$ with mean value of $56.11 \%$. Similar trend was recorded in yellow stem borer infestation after second spray (Table 4). It was recorded $2.08 \%$ dead heart before application of second spray as against 6.29 $\%$ in untreated control. Minimum infestation (1.67\%) was reported at 5 days after application of second spray as compared to $6.45 \%$ in untreated control. Infestation of stem borer increased at 10 days after application. Yellow stem borer infestation was recorded $1.08 \%$ dead heart as compared to $6.56 \%$ in untreated control (Table 4). Trend was similar in yellow stem borer infestation after second spray based on the per cent reduction in dead hearts over 

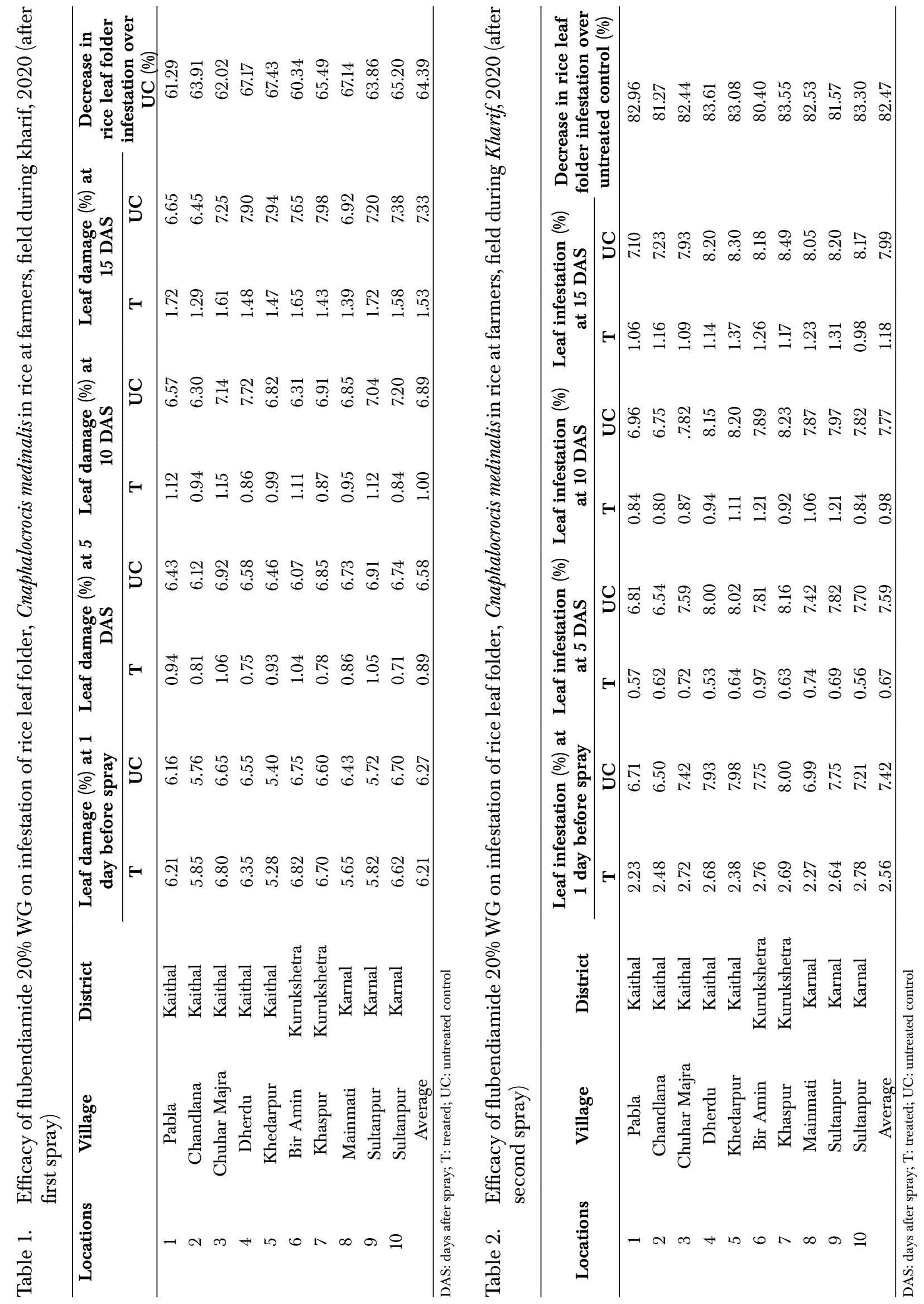
Flubendiamide 20WG efficacy against rice leaffolder and yellow stem borer
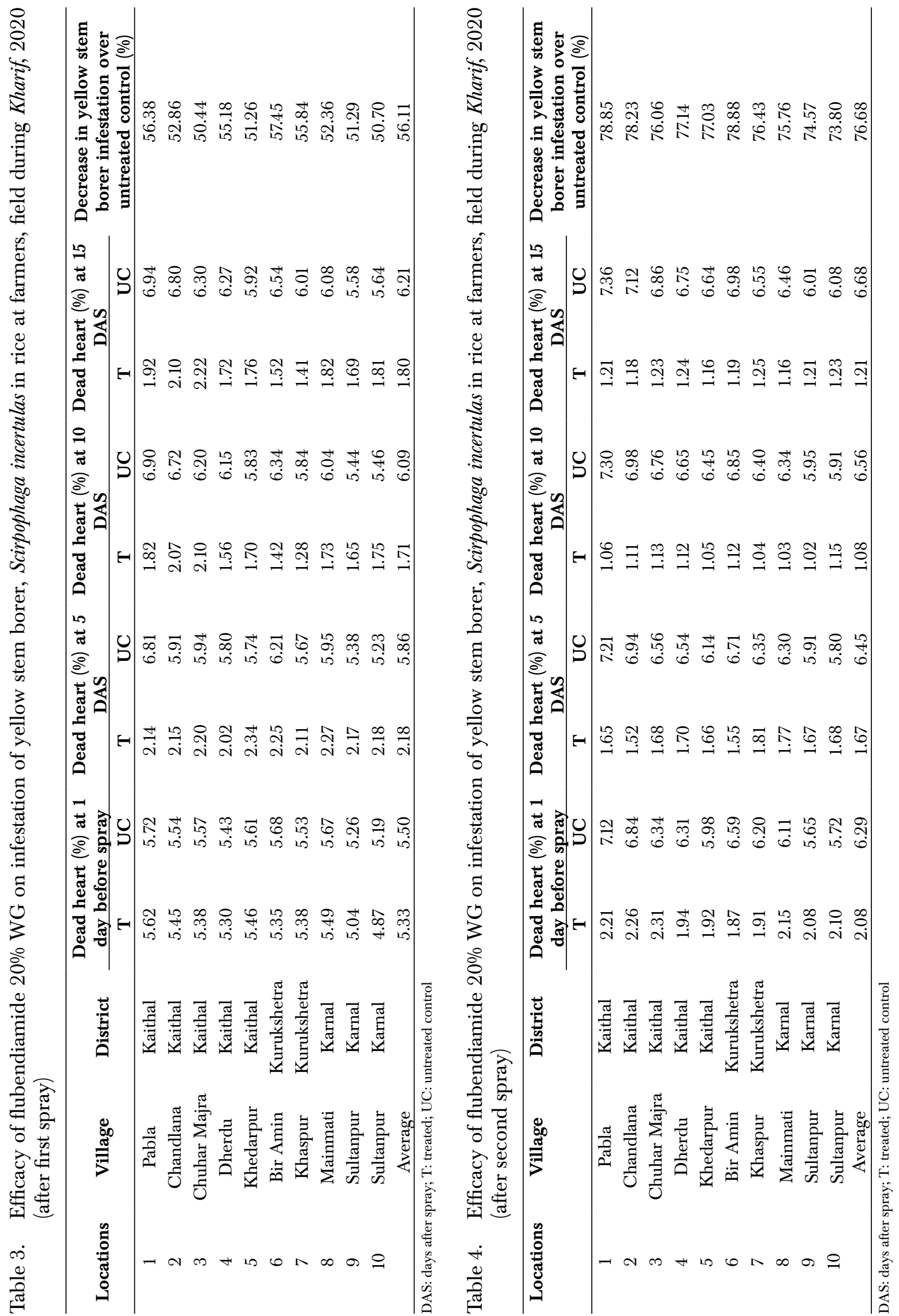


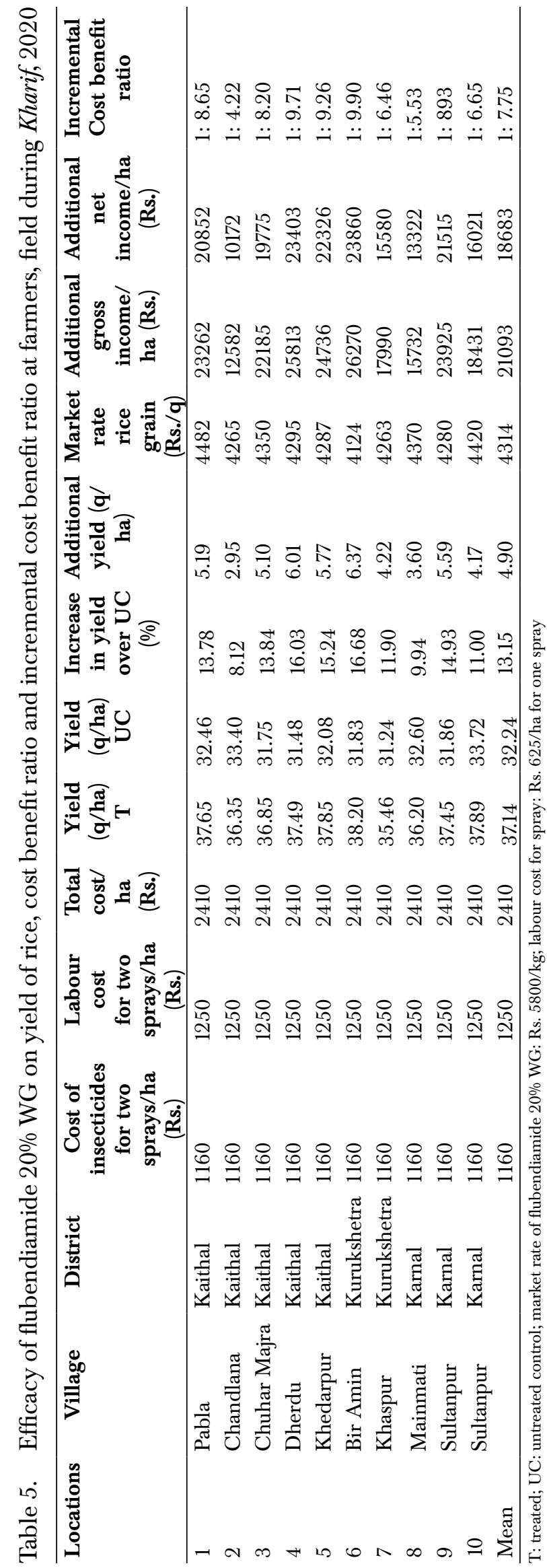

the untreated control as in first spray (Table 4). Mean per cent reduction over control was recoded $76.68 \%$.

Our results indicated that there was no difference in terms of leaf damage and dead hearts before insecticidal applications against rice leaf folder and yellow stem borer in rice. After both the applications, flubendiamide 20 WG @ 25 g a.i. ha ${ }^{-1}$ markedly reduced leaf and stem damage as compared to untreated control. Similar results were observed by Hurali et al. (2019) who reported that flubendiamide 0.7 GR @ $100 \mathrm{~g}$ a.i. ha ${ }^{-1}$ gave maximum per cent reduction over control in case of dead hearts ( 85.68 \& 85.48 ) in rice during Kharif, 2015 and 2016, respectively. Similarly, highest efficacy of flubendiamide against rice insect pests (rice leaf folder and yellow stem borer) was observed by Reddy et al. (2019) and Randhawa et al. (2018). Arulkumar et al. (2019) investigated effect of foliar spray of flubendiamide $20 \mathrm{WG}$ on infestation of yellow stem borer infestation in rice. They reported infestation of yellow stem borer to be $6.48 \%$ dead heart after two sprays of flubendiamide 20 WG @ $25 \mathrm{~g}$ a.i. ha ${ }^{-1}$ as against 19.81\% in untreated control. Studies of Zala and Sipai (2021) who reported that application of flubendiamide 20 WG @ $25 \mathrm{~g}$ a.i. ha ${ }^{-1}$ recorded $12.51 \%$ leaf damage infestation of C. medinalis as against $28.21 \%$ in untreated control also support present investigations. Seni (2019) made studies on spray of novel insecticide, Rynaxypyr 20 SC @ $150 \mathrm{ml}$ $\mathrm{ha}^{-1}$ and reported that yellow stem borer infestation was recorded 3.63\% (dead heart) in treated plots as compared to $8.66 \%$ in control partially support present investigations.

No phyto toxicity symptoms viz, leaf tip burning, leaf chlorosis, vein clearing, leaf necrosis, leaf epinasty, leaf hyponasty, wilting, stunting and hyponasty were inflicted by flubendiamide 20 WG @ $25 \mathrm{~g}$ a.i. ha ${ }^{-1}$ on the rice crop during kharif, 2020. Similarly, Sudhanan et al. (2017) did not observe any phyto toxicity symptom of flubendiamide 20 WG @ 50, 100 and $200 \mathrm{~g}$ a.i. ha ${ }^{-1}$ in sugarcane crop partially support present investigations.

Average grain yield $(37.14 \mathrm{q} / \mathrm{ha})$ was observed from different multi-location trials in twice application of flubendiamide20WG@25 gm a.i. ha ${ }^{-1}$ as compared to untreated control (32.24 q/ha). Average per cent increase in yield over untreated control at 10 locations was recorded to be $13.15 \%$ (Table 5). Incremental cost benefit ratio in flubendiamide $20 \mathrm{WG} @ 25 \mathrm{~g}$ a.i. ha ${ }^{-1}$ was recorded to be 1: 7.75 (Table 5). Results of Zala and Sipai 
(2021) who recorded rice yield of $54.01 \mathrm{q} \mathrm{ha}^{-1}$ in two sprays of flubendiamide 20 WG @ 25 gm a.i. ha ${ }^{-1}$ as compared to $34.33 \mathrm{q} \mathrm{ha}^{-1}$ in untreated control support present findings. Similarly, in a fungicide and insecticide compatibility experiment, Biswas (2012) found that flubendiamide 480 $\mathrm{SC}$ increased the rice grain yield by $3875 \mathrm{~kg} \mathrm{ha}^{-1}$. Ghoghari et al. (2019) conducted experiment for control of yellow stem borer in rice and exhibited that flubendiamide 20 WG@ $2.5 \mathrm{~g}$ per 10 liters of water gave maximum yield $67.59 \mathrm{qha}^{-1}$ ) as compared to the other treatments. Hurali et al. (2019) showed that flubendiamide 0.7\% GR @ $100 \mathrm{~g}$ a.i. ha ${ }^{-1}$ gave maximum grain yield of rice i.e., 66.29 and $69.14 \mathrm{q} \mathrm{ha}^{-1}$ during Kharif, 2015 and 2016, respectively. Literature is silent with regard to ICBR in rice. However, Sridhar and Sharma (2015) investigated that application of flubendiamide 20 WG @ 60 g a.i. ha- ${ }^{1}$ was found most effective with better incremental cost benefit ratio as compared to the check insecticides in soybean crop.

\section{Conclusion}

The results of present investigations on evaluation of efficacy of flubendiamide $20 \%$ WG against rice leaf folder and yellow stem borer in basmati rice concluded that spray of flubendiamide 20 WG @ 25 g a.i. ha ${ }^{-1}$ in 500 litre water ha ${ }^{-1}$ first at the tillering stage (30 DAT) and second at panicle initiation stage (50 DAT) or when pests crosses ETL was found as an effective insecticidal treatment in reducing infestation of both pests drastically with no phyto toxicity symptoms and increased grain yield.

\section{Acknowledgement}

The authors are thankful to the Director Research, CCS Haryana Agricultural University, Hisar for providing necessary facilities and Rallis India Limited to provide funds for testing of chemical in trade name of Takumi $20 \mathrm{WG}$.

\section{Conflict of Interest}

Authors declare that they do not have any conflict of interest.

\section{Ethical Compliance Statement}

NA

\section{Authors' Contribution}

Designing of experiment, data collection, analysis and preparation of manuscript by both authors (MSJ \& OPC).

\section{References}

1. Ambarish S, AP Biradar and SB Jagginavar. 2017. Phytotoxicity and their bio-efficacy of pesticides against key insect pests of Rabi sorghum [Sorghum bicolor (L.) Moench]. Journal of Entomology and Zoology Studies 5 (2): 716-720.

2. Anonymous. 2012. Annual Report 2010-11, Department of Agriculture and Cooperation, Ministry of Agriculture, Government of India, $31 \mathrm{p}$.

3. Anonymous. 2019. Package of practices for kharif crops. Published by Publication cell, Directorate of Extension Education, CCS Haryana Agricultural University, Hisar, pp 1-37.

4. Arulkumar G, YSJT Edward, K Bhuvaneswari, P Jeyaprakash, NC Sekaran, M Senthilkumar. 2019. Effects of flubendiamide and a lactic acid bacterial formulation on stem borer, Scirpophaga incertulas Walker and its parasitoids in rice. International Journal of Current Microbiology and Applied Sciences $\mathbf{8}$ (11):613-633.

5. Biswas A. 2012. Evaluation of bio-efficacy and compatibility of fungicide and insecticide against sheath blight and stem borer in rice. Pestology 36 (7):34-36.

6. Ghoghari PD, RL Chavadhari, VA Patil and NK Kavad. 2019. Bio-efficacy of insecticides against rice stem borer, Scirpophaga spp. International Journal of Entomological Research 4 (4):59-65.

7. Hurali S, RB Vinoda, H Mahantashivayogayya, D Pramesh and SB Gowdar. 2019. Evaluation of new generation granular insecticides against major lepidopteran pests of rice, Oryza sativa L. International Journal of Chemical Studies 8 (1):1047-1051.

8. Muhammad A, S Anjum, MM Majeed, MJ Arif, B Hazrat, MD Gogi and MH Bashir. 2012. Determination of Economic Threshold Level (ETL) for the chemical control of rice leaf folder, Cnaphalocrocis medinalis (Pyralidae: Lepidoptera). Pakistan Entomology 34 (1):79-81.

9. Muralidharan K and IC Pasalu. 2006. Assessments of crop losses in rice ecosystems due to stem borer damage. Crop Protection 25 (5): 409-417. 
10. Pallavi D, Sharanabasappa and GK Girijesh. 2017. Crop loss estimation of yellow stem borer, Scirpophaga incertulas (Walker) damage on paddy. Journal of Entomology and Zoology Studies 5 (6): 635-638

11. Randhawa HS, SS Aulakh and MK Saini. 2018. Evaluation of insecticides against stem borer and rice leaf folder in basmati rice. Indian Journal of Entomology 80 (3):715-719.

12. Reddy LPV, SRK Rao, TM Krishna, CS Rao, B Padmodaya and GM Naidu. 2019. Bio-efficacy of certain insecticides against rice yellow stem borer, Scirpophaga incertulas (Walker). Journal of Pharmacognosy and Phytochemistry 8 (4):2625-2628.

13. Rahaman MM and MJ Stout. 2019. Comparative efficacies of next-generation insecticides against yellow stem borer and their effects on natural enemies in rice ecosystem. Rice Science 26 (3): 157166.

14. Seni A. 2019. Impact of certain essential oils and insecticides against major insect pests and natural enemies in rice. Journal of Cereal Research 11(3): 252-256.
15. Sridhar Y and AN Sharma. 2015. Flubendiamide, a novel insecticide for management of lepidopteron defoliators in soybean. Legume Research 38: 551-554.

16. Sudhanan EM, SV Krishnamoorthy and S Kuttalam. 2017. Bio-efficacy, phyto toxicity, safety to natural enemies and residues of flubendiamide in sugarcane (Saccharum spp. L.) under field conditions. Crop Protection 100:21-28.

17. Teng PS, KL Heong and K Moody. 1993. Advances in tropical rice integrated pest management research. In: Muralidharan K, Siddiq EA (eds) New frontiers in rice research, Directorate of Rice Research, Hyderabad, India, pp 241-255.

18. Tohnishi M, H Nakao, T Furuya, A Seo, H Kodama and K Tsubata. 2005. Flubendiamide, a novel insecticide highly active against lepidopterous insect pests. Journal of Pesticide Science 30 (4):354-360.

19. Zala MB and SA Sipai. 2021. Efficacy of insecticides against rice leaf folder, Cnaphalocrocis medinalis (Guenee). The Pharma Innovation Journal 10(12S):874879 . 